doi: 10.32620/oikit.2020.90.08

УДК 623.465

\author{
В.І. Макеєв ${ }^{1}$, В.В. Воронько ${ }^{2}$, Ю.І. Пушкарьов ${ }^{1}$, \\ П.І. Гайда ${ }^{1}$, О.Ю. Пащук ${ }^{3}$
}

\title{
Особливості визначення витрати снарядів і способу обстрілу колон противника
}

\author{
${ }^{1}$ Кафредра військової підготовки Сумського державного університету \\ ${ }^{2}$ Харківський національний університет міського господарства \\ імені О.М. Бекетова \\ ${ }^{3}$ Національний аерокосмічний університет ім. М.Є. Жуковського «ХАl»
}

Колони, які $\epsilon$ високоманевреними цілями і будь-які інші цілі, вражають 3 метою нанесення збитку противникові. В результаті обстрілу колон противника порушується планомірне висунення і розгортання його резервів, порушується управління, створюються сприятливі умови для застосування ефективніших видів вогню інших засобів ураження. Результат вогню артилерії зазвичай характеризують математичним сподіванням безповоротного збитку і часом затримки колони противника або показником $W_{\text {оз }}$, який характеризує збиток, що наноситься угрупуванню противника внаслідок затримки колони і нанесення їй безповоротного збитку.

Стаття складається $з$ наступних розділів:

1. Показники ефективності під час ураження колон противника;

2. Залежність витрати снарядів і способу обстрілу цілі від умов виконання вогневого завдання;

3. Залежність витрати снарядів від необхідного рівня показника ефективності стрільби на ураження;

4. Залежність витрати снарядів від способу визначення установок для стрільби на ураження і розмір групової цілі;

5. Залежність витрати снарядів від кількості вогневих засобів, що притягуються для ураження цілі, і дальності стрільби;

6. Залежність витрати снарядів від характеристик вражаючої дії боєприпасів і способу обстрілу цілі;

7. Залежність способу обстрілу цілі від різних чинників.

У статті розглянуті математичні залежності для визначення показників ефективності ураження колон, витрати снарядів, способу обстрілу колон. Розглянута ймовірність накриття колони на основі закону рівномірного розсіювання. Отримані розміри зон рівномірного розсіювання на основі дисперсії найвигіднішого розсіювання. У статті наведені залежності витрат снарядів і способу обстрілу цілі від умов виконання вогневого завдання, виходячи 3 вимог досягнення заданого ступеня ураження (необхідного рівня показника ефективності). Досліджені питання залежності витрати снарядів від необхідного рівня показника ефективності стрільби на ураження, і від способу визначення установок для стрільби на ураження і розмірів групової мети. Розглянуті питання залежності витрати снарядів від умов виконання вогневого завдання. Ключові слова: математичне очікування, вірогідність, витрата снарядів, закон рівномірного розсіювання, дисперсія, серединні помилки, приведена зона ураження, параметри способу обстрілу.

\section{1. Показники ефективності під час ураження колон противника}

Пересування військ противника здійснюється, як правило, поза видимістю 3 наземних спостережних пунктів, тому колони противника відносять до неспостережуваних цілей. Ураження колон противника здійснюють в наміченій точці зустрічі. Оцінку ефективності стрільби по колоні можна проводити за 
формулою, ґрунтованій на допущенні про рівномірне розсіювання снарядів [1].

$$
M=\Theta\left(1-e^{-\frac{N S_{n}}{S_{3 p p}}}\right)
$$

де $N$ - витрата снарядів під час ураження колон;

$S_{n}$ - приведена зона ураження.

Витрату снарядів для ураження нерухомих цілей визначають виходячи 3 необхідного рівня показника ефективності стрільби ( $M$ ). В даному випадку такий підхід неможливий, оскільки у разі обстрілу колона противника може розосередитися і вийти із зони обстрілу. Час виходу окремих цілей із зони обстрілу випадково і визначається маневреними можливостями окремих цілей, умовами місцевості і розмірами області обстрілу цілі і в середньому складає 2-3 хвилини. Позначимо математичне сподівання часу виходу окремих цілей із зони обстрілу $\bar{t}$. Кількість снарядів, яку може витратити артилерія на час виходу окремих цілей з зони обстрілу $\bar{t}$, обмежено режимом вогню. Тому витрату снарядів, яку доцільно призначати для ураження колон противника $(N)$, приймемо рівну кількість снарядів, яка може витратити артилерія, що залучається, за час виходу окремих цілей із зони обстрілу.

$$
N=N_{p o}(\bar{t}) k_{\text {гар }}
$$

де $N_{p в}(\bar{t})$ - витрата снарядів за режимом вогню однієї гармати за час $\bar{t}$;

$k_{\text {гар }}$ - кількість гармат, що залучається до стрільби.

Для визначення часу виходу окремих цілей із зони обстрілу необхідно знати розміри зони рівномірного розсіювання снарядів $\left(S_{\text {зрр }}\right)$. При ураженні нерухомих цілей оптимальні розміри зони рівномірного розсіювання снарядів визначають виходячи з необхідного рівня показника ефективності стрільби $(M)$. В даному випадку такий підхід неможливий, оскільки необхідний рівень показника ефективності стрільби $(M)$ не встановлений.

Ураження цілі можливе тільки у тому випадку, якщо підчас проходження колоною противника наміченої точки зустрічі вона (точка зустрічі) буде накрита областю обстрілу. Імовірність накриття цілі зоною рівномірного розсіювання характеризує значення $\Theta$. Тому в якості приватного показника ефективності стрільби прийом імовірності накриття наміченої точки зустрічі зоною рівномірного розсіювання. Необхідне значення рівня показника ефективності стрільби, як і при ураженні інших окремих цілей, прийом ідентичний $\Theta=0,8$. Імовірність накриття наміченої точки зустрічі зоною рівномірного розсіювання визначається за фрормулою [1].

$$
\Theta=\hat{\Phi}\left(\beta_{1}\right) \hat{\Phi}\left(\beta_{2}\right)=\hat{\Phi}\left(\frac{\Gamma_{3 p p}}{2 E \partial o}\right) \hat{\Phi}\left(\frac{\Phi_{3 p p}}{2 E н o}\right) .
$$

Залежно від параметрів способу обстрілу розміри зони рівномірного розсіювання снарядів змінюватимуться. Щоб визначити оптимальні розміри зони рівномірного розсіювання необхідно досліджувати на максимум залежність (3). Для цього досить узяти похідну і прирівняти її нулю. В результаті розв'язання цієї задачі доведено, що максимальне значення $\Theta$ досягається у тому випадку, якщо 
$\beta_{1}=\beta_{2}$, тобто за умови, що дотримується рівність

$$
\frac{\Gamma_{\text {зрp }}}{E \partial o}=\frac{\Phi_{\text {зрp }}}{E н о} .
$$

В цьому випадку $\hat{\Phi}\left(\beta_{1}\right)=\hat{\Phi}\left(\beta_{2}\right)$ i, отже, максимальне значення ймовірності накриття цілі (точки зустрічі) зоною рівномірного розсіювання визначається за формулою

$$
\Theta=\stackrel{\wedge}{\Phi}^{2}(\beta)
$$

Щоб визначити оптимальні розміри зони рівномірного розсіювання снарядів необхідно визначити чисельне значення $\beta$. Для цього запишемо $\hat{\Phi}(\beta)=\sqrt{\Theta}$. Підставивши необхідне значення $\Theta=0,8$, отримаємо $\hat{\Phi}(\beta)=\sqrt{0,8} \approx 0,9$. Використовуючи таблицю чисельних значень функції $\hat{\Phi}(\beta)$ [2] по ймовірності $\Theta=\hat{\Phi}(\beta)=0,9$ знаходимо значення $\beta=2,44$. Отже, $\Theta=0,8$, якщо $\beta_{1}=\beta_{2}=2,44$. Значення $\beta$ визначають за формулою (3) з урахуванням якої запишемо

$$
\beta_{1}=\beta_{2}=\frac{\Gamma_{3 p p}}{2 E \partial o}=\frac{\Phi_{3 p p}}{2 E н о}=2,44
$$

Використовуючи отримане співвідношення, визначимо найвигідніші розміри зони рівномірного розсіювання снарядів:

$$
\begin{array}{ll}
\text { за дальністю } & \Gamma_{\text {зрр }}=4,88 E \partial о \\
\text { за напрямком } & \Phi_{\text {зрр }}=4,88 E \text { но }
\end{array}
$$

Визначивши розміри зони рівномірного розсіювання снарядів, запишемо дисперсію рівномірного найвигіднішого розсіювання [1];

за дальністю $Д(x)=\frac{\Gamma_{3 p p}^{2}}{12}=\frac{(4,88 E \partial o)^{2}}{12}=1,99 E \partial o^{2} \approx 2 E \partial o^{2} ;$
за напрямком $Д(z)=\frac{\Phi_{3 p p}^{2}}{12}=\frac{(4,88 E н o)^{2}}{12}=1,99 E н o^{2} \approx 2 E н o^{2} ;$

Прирівняємо дисперсію рівномірного найвигіднішого розсіювання дисперсії реального розсіювання. Так, прирівнявши дисперсію рівномірного найвигіднішого розсіювання снарядів за дальністю (8) дисперсії реального розсіювання (10),

$$
Д(x)=\frac{\left(n_{\sigma}^{2}-1\right)}{12} h_{x}^{2}+T_{x}(l, m) B \partial o^{2} .
$$

Отримаємо зведену серединну помилку в дальності

отже

$$
2 E \partial o^{2}=\frac{\left(n_{\text {zap }}^{2}-1\right)}{12} h_{x}^{2}+T_{x}(l, m) B \partial o^{2} .
$$




$$
h_{x}=\sqrt{\frac{12}{n_{\sigma}^{2}-1}\left[2 E \partial o^{2}-T_{x}(l, m) B \partial o^{2}\right]} .
$$

Аналогічно отримана формула для визначення відстані між точками прицілювання за напрямком

$$
h_{z}=\sqrt{\frac{12}{n_{\text {zap }}^{2}-1}\left[2 E н o^{2}-T_{z}(m, l) B \sigma o^{2}\right]} .
$$

Приклад 1. Визначити параметри способу обстрілу колони бронетранспортерів дивізіоном $2 C 3$ в наміченій точці зустрічі, якщо дальність стрільби 16000 м. Зведені серединні характеристики $E \partial o=99$ м, Вдо=78 м, $E н о=52$ м, Вбо $=27$ м [3]. Приведена площа ураження бронетранспортера $S_{n}=41 \mathrm{M}^{2}$ [2].

Розв'язання 1. Розрахункові формули

2. Вхідні величини.

$$
\begin{gathered}
h_{x}=\sqrt{\frac{12}{n_{\sigma}^{2}-1}\left[2 E \partial o^{2}-T_{x}(l, m) B \partial o^{2}\right]} . \\
h_{z}=\sqrt{\frac{12}{n_{\text {zap }}^{2}-1}\left[2 E н o^{2}-T_{z}(m, l) B \sigma o^{2}\right]} .
\end{gathered}
$$

Приймемо $n_{б}=3$ (по кількості батарей в дивізіоні), $n_{\text {гар }}=6$ (по кількості гармат в батареї)

$$
\left.\begin{array}{l}
l=\frac{l_{n}}{\text { Вдо }}=\frac{3,2}{78}=0,14 \\
m=\frac{m_{n}}{\text { Вбо }}=\frac{3,2}{27}=0,5
\end{array}\right\} \stackrel{\text { Табл }}{\longrightarrow}\left\{\begin{array}{l}
T_{x}(l, m)=2,20, \\
T_{z}(m, l)=2,21 .
\end{array}\right.
$$

Таблиця $T_{x}(l, m) ; T_{z}(l, m)$ [3]

3. Розрахунки.

$$
h_{x}=\sqrt{\frac{12}{3^{2}-1}\left[2 \cdot 99^{2}-2,20 \cdot 78^{2}\right]}=97 \mathcal{M} ; h_{z}=\sqrt{\frac{12}{6^{2}-1}\left[2 \cdot 52^{2}-2,21 \cdot 26^{2}\right]}=37 \text {. }
$$

Стрільбу на ураження колон противника доцільно вести шкалою на одній установці кутоміра. В цьому випадку не витрачається час на зміну установок в ході стрільби на ураження i, отже, досягається більший ступінь ураження цілі. Якщо колона противника має значні розміри, то для ії ураження може залучатися артилерійська група. В цьому випадку доцільно обстріл цілі вести по усій глибині цілі. Відстань між точками прицілювання для дивізіонів, що залучаються, може бути призначена рівною глибині дивізійного еліпса розсіювання. Так, в умовах прикладу 1 , під час стрільби на трьох установках прицілу відстань між ближньою і дальньою точками прицілювання складає 194 м [3]. Відносно ближньої і дальньої точки прицілювання відбувається розсіювання, а це ще по $3-4 B \partial о$ в кожний бік, тобто $3,5 \cdot 78 \cdot 2=546$ м. Разом $740 \mathrm{м} \approx 700$ м. Формулу для визначення відстані між точками прицілювання можна представити у вигляді 


$$
l_{x}=\left(n_{\sigma}-1\right) h_{x}+2(3 \ldots 4) \text { Вдо }
$$

де $l_{x}$ - відстань між точками прицілювання.

Для підвищення ефективності вогню, якщо дозволяють умови, необхідно по кожній точці прицілювання залучати декілька дивізіонів.

\section{2. Залежність витрати снарядів і способу обстрілу цілі від умов виконання вогневого завдання}

Розглянуті способи визначення витрати снарядів і визначення параметрів способу обстрілу цілі розроблені виходячи з вимоги досягнення заданого ступеня ураження цілі (необхідного рівня показника ефективності стрільби $M$ або $P$ ). В цьому випадку ефективність стрільби залежить, в основному, від витрати снарядів і способу обстрілу цілі. Розглянемо залежність витрати снарядів і способу обстрілу цілі від різних чинників.

Витрата снарядів, необхідна для ураження групової цілі при найвигіднішому способі її обстрілу визначається за формулою:

$$
N=K \frac{E \partial o^{\prime} E н o^{\prime}}{S_{n}}
$$

Аналізуючи цю фрормулу, відмітимо, що витрата снарядів знаходиться в зворотній пропорційній залежності від характеристики вражаючої дії боєприпасів $S_{n}$ і в прямій пропорційній залежності від характеристик точності визначення установок для стрільби на ураження і коефіцієнта $K$, чисельне значення якого визначається необхідним рівнем показника ефективності стрільби [3]. Розглянемо вплив кожного з цих чинників на витрату снарядів.

\section{3. Залежність витрати снарядів від необхідного рівня показника ефективності стрільби на ураження}

При ураженні групових цілей розрізняють два основні завдання стрільби: придушення і знищення цілі. Основним завданням стрільби на ураження групової цілі $€$ стрільба на придушення. Під час стрільби на придушення групової цілі необхідний рівень показника ефективності стрільби зазвичай приймають рівним $30 \%$, при стрільбі на знищення 50-60\%. Значення коефіцієнта $K$, відповідного $M=30 \%$, відповідно таблиці [2], складає $K=8,69$. При рівні показника ефективності стрільби $M=50-60 \%$ коефіцієнт $K$ рівний 20,82-30,65 або в середньому, при $M=55 \%$ його значення складає $K=25,29$ [2]. Отже, якщо витрата снарядів розрахована для стрільби на придушення, то для знищення цілі в цих умовах необхідно витрату снарядів збільшити в $25,29 / 8,69=2,91$ разів (приблизно у 3 рази). Знання цієї закономірності дозволяє в більш простому вигляді представити практичні рекомендації за витратою снарядів.

Для практики певний інтерес представляє співвідношення між витратою снарядів і зміною показника ефективності стрільби на $1 \%$. Визначимо цю залежність. Для рівня показника ефективності стрільби $M=30 \%$ значення $K=8,69$ [3]. При рівні показника ефективності стрільби $M=29 \%$ значення коефріцієнта, розраховане за формулою, складає 8,27 [3]. Отже, зміни показника 
ефрективності стрільби на $1 \%$ відповідає зміні витрати снарядів на $(8,69-8,27) / 8,69=0,048$, тобто приблизно на $5 \%$. Виконавши аналогічні розрахунки при різному рівні показника ефективності стрільби, помічаємо, що ця зміна не $\epsilon$ постійною. При рівні показника ефективності $M=55 \%$ зміною показника ефективності стрільби на $1 \%$ відповідає зміні витрати снарядів на $4 \%$. При рівні показника ефективності $M=15 \%$ зміною показника ефрективності стрільби на $1 \%$ відповідає зміні витрати снарядів на $8 \%$.

Отже, зміні показника ефективності стрільби на $1 \%$ відповідає зміні витрати снарядів від 4 до 8\% (в середньому, на 6\%). Цю залежність доцільно використати під час оцінювання ефективності можливих варіантів рішення на виконання вогневого завдання за показником $M$. Якщо варіант прийнятого рішення відрізняється від найвигіднішого і характеризується зниженням показника ефективності стрільби усього лише на $1 \%$, то це означає, що $6 \%$ витрати снарядів витрачений марно. Якщо врахувати, що витрату снарядів для ураження групової цілі досить велике, то $6 \%$ від його, величина дуже істотна.

\section{4. Залежність витрати снарядів від способу визначення установок для стрільби на ураження і розмір групової цілі}

Основним способом визначення установок для стрільби по неспостережуваних цілях являється повна підготовка. Середні значення серединних помилок повної підготовки для нарізних гармат складають $E_{x}=0,7 . .0,9 \%$ д і $E_{z}=0-0,3 \ldots 0-0,5$ [3]. Витрата снарядів прямо пропорційна здійсненню помилок. Тому, при визначенні установок для стрільби на ураження способом, що відрізняється від основного, витрату снарядів необхідно змінювати в стільки разів, в скільки разів, в середньому, здійснення помилок цього способу більше або менше здійснення помилок повної підготовки.

Серединні помилки під час перенесення вогню від репера на геодезичній основі характеризуються серединними помилками по дальності $E_{x}=0,5 \ldots 0,7 \%$ Д і напрямку $E_{z}=0-0,3 \ldots 0-0,4$ [3]. Отже, при перенесеннях вогню витрату снарядів слід змінювати в $k$ разів

$$
k=\frac{(0,5 \ldots 0,7)(3 \ldots 4)}{(0,7 \ldots 0,9)(3 \ldots 5)}=\frac{0,6 \cdot 3,5}{0,8 \cdot 4}=0,7
$$

тобто призначати витрату снарядів рівний $70 \%$ від витрати снарядів, розрахованої для повної підготовки (зменшувати на $30 \%$ ). Проте, це співвідношення справедливе під час перенесення вогню по окремій цілі. Розглянемо, як зміниться це співвідношення під час ураження групової цілі.

Нехай дальність стрільби 10000 м, ціль 300 м по фронту і 200 м по глибині. Серединні помилки підготовки при стрільбі по окремій цілі в цьому випадку складають [2]:

$\begin{array}{lll}\text { перенесення вогню: } & E_{x}=0,6 \cdot 100=60 \mu, & E_{z}=3,5 \cdot 10=35 \\ \text { п; }\end{array}$ повна підготовка: $\quad E_{x}=0,8 \cdot 100=80 \mathcal{M}, \quad E_{z}=4 \cdot 10=40 \mathcal{M}$

Серединні помилки підготовки при стрільбі по груповій цілі рівні: перенесення вогню: 
$E_{x}^{\prime}=\sqrt{60^{2}+0,038 \cdot 200^{2}}=72 \mu, \quad E_{z}^{\prime}=\sqrt{35^{2}+0,038 \cdot 300^{2}}=68 \mu ;$ повна підготовка:

$E_{x}^{\prime}=\sqrt{80^{2}+0,038 \cdot 200^{2}}=89 \mu, \quad E_{z}^{\prime}=\sqrt{40^{2}+0,038 \cdot 300^{2}}=71$..

Відношення твору серединних помилок $k=\frac{72 \cdot 68}{89 \cdot 71}=0,78$.

В умовах розглянутого прикладу, при перенесенні вогню витрату снарядів можна зменшити на 22\% . 3 розглянутого прикладу слідують висновки:

- зі збільшенням площі цілі вплив точності на ефективність вогню зменшується, тому при ураженні групових цілей, якщо чинник несподіваності має вирішальне значення, можуть застосовуватися і менш точні способи;

- зі збільшенням розмірів групової цілі характеристики точності $E_{x}^{\prime}$ і $E_{z}^{\prime}$ збільшуються; чим більше площа цілі, тим більше витрат снарядів потрібна для іï ураження з необхідним ступенем ураження;

- під час перенесення вогню від репера витрата снарядів може бути зменшена на $25 \%$ (на 1/4) відносно витрат снарядів, розрахованих для повної підготовки.

Аналогічно визначена зміна витрати снарядів у разі, коли установки для стрільби на ураження визначені способом скороченої підготовки. Серединні помилки скороченої підготовки в середньому 1,3 рази більше, ніж при повній підготовці. Відношення множення серединних помилок під час ураження окремої цілі в цьому випадку рівно $k=1,7$. Зі збільшенням розмірів цілі це відношення зменшується. Отже, у разі, коли установки для стрільби на ураження визначені способом скороченої підготовки, витрата снарядів може бути збільшена в 1,5 разів.

При стрільбі реактивної артилерії серединні помилки скороченої і повної підготовки практично однакові. Тому допустимо вважати, що витрата снарядів при стрільбі реактивної артилерії не залежить від способу визначення установок.

\section{5. Залежність витрати снарядів від кількості вогневих засобів, що притягуються для ураження цілі, і дальності стрільби}

Серединні помилки підготовки залежать не лише від способу визначення установок для стрільби на ураження, але і від дальності стрільби і кількості вогневих засобів, що притягаються. Аналізуючи залежності, по яких розраховуються зведені серединні помилки визначення установок для стрільби,

$$
E \partial o=\sqrt{E_{x \partial}^{2}+\frac{E_{x \sigma}^{2}}{m}+\frac{E_{x z a p}^{2}}{m k}}
$$

де $E_{x \partial}, E_{x \sigma}, E_{x z а р}-$ серединні помилки дивізійні, батарейні, гарматні;

$m$ - кількість батарей;

$k$ - кількість гармат в батареї.

Відмітимо, що кількість гармат і кількість батарей записане в знаменнику. Тому, зі збільшенням кількості вогневих засобів, що залучаються для стрільби на ураження, зведені серединні помилки підготовки Едо і Ено зменшуються. 
Отже, якщо витрата снарядів розрахована для основного тактичного підрозділу, то у разі залучення більшої кількості вогневих засобів витрата снарядів може бути зменшена. У разі залучення меншої кількості вогневих засобів витрата снарядів може бути збільшена.

Значення зведених серединних помилок при стрільбі дивізіону і батареї під час визначення установок для стрільби способом повної підготовки на дальність 8000 м зведені серединні помилки підготовки рівні $E \partial o=58$ м, $E н o=35$ м у разі стрільби дивізіоном і $E \partial о=64$ м, Ено $=40$ м під час стрільби батареєю [3]. Визначимо відношення здійснення зведених серединних помилок

$$
k=\frac{64 \cdot 40}{58 \cdot 35}=1,26
$$

можна зробити висновок, що під час ураження окремої неспостережуваної цілі вогнем батареї, витрату снарядів необхідно збільшити (в умовах прикладу на $26 \%$ ).

Залучення більшої кількості артилерії веде не лише до зменшення зведених серединних помилок підготовки, але і дозволяє створити більш високу щільність розривів, що веде до підвищення ефективності вогню. Тому, під час ураження цілі зосередженим вогнем артилерійської групи або масованим вогнем артилерії витрата снарядів може бути зменшена.

\section{6. Залежність витрати снарядів від характеристик вражаючої дії боєприпасів і способу обстрілу цілі}

Витрата снарядів обернено пропорційна до приведеної площі ураження окремої цілі. Отже, чим більше $S_{n}$, тим менше вимагається снарядів для ії ураження і навпаки. Характеристики вражаючої дії боєприпасів під час стрільби по різних цілях приведені в спеціальній літературі $[2,3]$. Необхідно відмітити, що вражаюча дія боєприпасів залежить від уразливості цілі, рівня ії захищеності, могутності снаряда (калібру снаряда, виду вибухової речовини, наявності готових забійних елементів, основного вражаючого чинника), установки підривника, характеру ґрунту в районі цілі, від кута падіння снаряда, а при стрільбі в горах, крім того, від кута зустрічі. Зміна витрати снарядів, відносно основної, прийнятої при розрахунках, може бути врахована за допомогою коефріцієнта, кількісно рівного відношенню приведених зон ураження.

Формула (15) отримана в пропозиції, що спосіб обстрілу цілі найвигідніший. Якщо спосіб обстрілу цілі відрізняється від найвигіднішого, то значення показника ефективності стрільби буде менше необхідного його значення. Необхідно відмітити, що у більшості випадків функції, досліджувані на екстремум, плавно змінюються в навколо екстремуму. Не $є$ виключенням і залежність витрати снарядів від способу обстрілу цілі. Дослідження показують, що відмінність відстані між точками прицілювання на одно серединне відхилення ( Вдо або Вбо) веде до зниження ступеня ураження, який не перевершує $1-2 \%$

\section{7. Залежність способу обстрілу цілі від різних чинників}

Параметри способу обстрілу цілі визначаються за фрормулами (12) і (13). Аналіз цих залежностей, дозволяє зробити наступні висновки:

1. Штучне розсіювання потрібне $h_{x}>0, h_{z}>0$ ), якщо різниця дисперсії 
найвигіднішого розсіювання снарядів і дисперсії розсіювання снарядів при реальному способі обстрілу цілі, поміщена в квадратні дужки, позитивна. Якщо ця різниця негативна, то стрільбу необхідно вести по одній точці прицілювання. Зі збільшенням числа точок прицілювання відстань між ними зменшується.

2. Відстань між точками прицілювання залежить від серединних помилок визначення установок для стрільби на ураження. Чим більше серединні помилки визначення установок, тим більшою має бути відстань між точками прицілювання. Зниження точності вогню, відносно основного способу визначення установок для стрільби на ураження, повинне супроводжуватися збільшенням відстані між точками прицілювання, а при визначенні установок точнішим способом - зменшенням.

3. Зі збільшенням необхідного рівня показника ефективності стрільби значення $y_{2}^{*}$ [2] зростає. Тому, під час стрільби по окремих і групових цілях незначних розмірів ( $\left.\Gamma_{u} \leq 10 E \partial o, \Phi_{u} \leq 10 E н о\right)$ [3] відстань між точками прицілювання повинна збільшуватися зі збільшенням необхідного рівня показника ефективності стрільби (під час стрільби на знищення більше, ніж під час стрільби на придушення). Під час стрільби по цілях значних розмірів $\left(\Gamma_{u} \geq 15 E \partial o, \Phi_{u} \geq 15 E н o\right)$ відстань між точками прицілювання не залежить від необхідного рівня показника ефективності стрільби.

4. Зі збільшенням серединних характеристик розсіювання відстань між точками прицілювання повинна зменшуватись. При стрільбі з артилерійських систем, що мають велике технічне розсіювання відстань між точками прицілювання має бути менша, ніж при стрільбі гармат з малим розсіюванням.

5. Значення фрунції $T_{x}(l, m)$ і $T_{z}(l, m)$ [3] залежить від вражаючої дії боєприпасів, чим більше характеристики вражаючої дії, тим більше їх значення. Отже, чим більше характеристики вражаючої дії боєприпасів, тим менше оптимальна відстань між точками прицілювання.

\section{Висновки}

1. У статті запропоновані показники ефективності і витрата снарядів під час ураження колон противника.

2. Приведені залежності для розрахунку параметрів способу обстрілу цілі за дальністю і напрямком.

3. Розглянуті залежності витрати снарядів і способу обстрілу цілі від умов виконання вогневого завдання.

4. Запропоновані математичні залежності витрати снарядів від способу визначення установок для стрільби на ураження, розмірів групової цілі і кількості вогневих засобів, що залучаються для стрільби.

\section{Список літератури}

1. Вентцель, О. С. Теорія ймовірності / О. С. Вентцель - М.: Державне видавництво фрізико-математичної літератури, 1958 р. - С. 163.

2. Теоретические основы стрельбы наземной артиллерии / А.С.Круковский, И.В.Осипов, К.Г. Власенко и др.; под ред. А.С. Круковского. М.: Воен. издательство, 1976. - 346с.

3. Теоретические основы управления огнем наземной артиллерии / 
Аверьянов А.И., Карев В.В., Коваленко В.В. и др.; под общ. ред. Аверьянова А.И. - Л.: Издание академии, 1978. - 454 с.

\section{References}

1. Ventcel, O. S. Teoriya jmovirnosti O. S. Ventcel [Probability theory]. Moscow, Derzhavne vydavnycztvo fizyko-matematychnoyi literatury Publ.,1958. 163 p.

2 Krukovskij, A.S.,Osipov, I.V., Vlasenko, K.G. i dr. Teoreticheskie osnovy strel'by nazemnoj artillerii [Theoretical foundations of ground artillery firing]. pod red. A.S. Krukovskogo. Moscow, Voen. izdatel'stvo Publ., 1976. 346 p.

3 Aver'janov, A.I., Karev, V.V., Kovalenko, V.V. i dr. Teoreticheskie osnovy upravlenija ognem nazemnoj artillerii [Theoretical foundations of ground artillery fire control]. pod obshh. red. Aver'janova A.I. Leningrad, Izdanie akademii Publ., 1978. 454 p.

Надійшла до редакції18.10.2020. Розглянуто редколегією 20.10.2020.

\section{Features of determining the consumption of shells and the method of shelling enemy columns}

Columns, which are highly maneuverable targets and any other targets, return the damage to the opponents. As a result of the shelling, the enemy column was informed about the systematic study and deployment of its reserves, management violations, and unfavorable conditions were created for the use of effective types of fire by other means of destruction. The result of artillery fire reveals a mathematical combination of irreversible damage and delay time of the enemy column or Woz, which is characterized by damage to the group counteracting due to the delayed columns and the adjustment of its irreversible damage.

The article consists of the following sections:

1. Indicators of effectiveness during the defeat of enemy columns;

2. The dependence of the consumption of shells and the method of firing at the target on the conditions of the fire task; efficiency;

3. Dependence of projectile consumption on the required level of firing

4. The dependence of the consumption of shells on the method of determining the installations for firing on the defeat and the size of the group target;

5 . The dependence of the consumption of shells on the number of fire means used to hit the target, and the firing range;

6. Dependence of projectile consumption on the characteristics of the impressive action of ammunition and the method of firing at the target;

7. The dependence of the method of firing at the target from various factors.

In the article mathematical dependences for definition of indicators of efficiency of defeat of columns, expense of shells, a way of firing of columns are considered. The probability of covering a column on the basis of the law of uniform scattering is considered. The sizes of zones of uniform scattering on the basis of a dispersion of the most favorable scattering are received.

The article shows the dependences of the cost of shells and the method of firing at the target from the conditions of the fire task, based on the requirements of 
achieving a given degree of damage (the required level of efficiency). The issues of the dependence of projectile consumption on the required level of the rate of effectiveness of firing at the damage, and the method of determining the installations for firing at the damage and the size of the group target. The questions of dependence of shell consumption on the conditions of the fire task are considered.

Keywords: mathematical expectation, probability, projectile consumption, law of uniform scattering, variance, mean errors, reduced area of impact, parameters of the firing method.

\section{Відомості про авторів:}

Макеєв Василь Ілліч - кандидат технічних наук, доцент. Доцент кафедри військової підготовки Сумського державного університету, м. Суми, Україна, еmail: info@kvp.sumdu.edu.ua., тел. 066-418-25-23.

Пушкарьов Юрій Іванович - кандидат військових наук, доцент. Доцент кафедри військової підготовки Сумського державного університету, м. Суми, Україна, e-mail: y.pushkarov@kvp.sumdu.edu.ua., тел. 066-418-25-23.

Воронько Віталій Володимирович - доктор технічних наук, професор. Профресор кафедри транспортних систем і логістики Харківський національний університет міського господарства імені О.М. Бекетова, м. Харків, Україна, еmail: Vitaliy.voronko@gmail.com, тел. 050-578-97-33.

Гайда Павло Іванович - кандидат військових наук, старший науковий співробітник. Доцент кафедри військової підготовки Сумського державного університету, м. Суми, Україна, e-mail: info@kvp.sumdu.edu.ua., тел. 066-397-5011.

Пащук Олександр Юрійович - асистент кафреди конструкцій та проектування ракетно-космічної техніки Національного аерокосмічного університету ім М.Є. Жуковського «XAl», м. Харків, Україна, e-mail: paschuc1@gmail.com, тел. 097-382-61-45.

\section{Information about the authors:}

Makeev Vasil - Candidate of Technical Sciences, Associate Professor. Associate Professor of Military Training, Sumy State University, Sumy, Ukraine, email: info@kvp.sumdu.edu.ua., phone 066-418-25-23.

Pushkarov Yuriy - Candidate of Military Sciences, Associate Professor. Associate Professor, Department of Military Training, Sumy State University, Sumy, Ukraine, e-mail: y.pushkarov@kvp.sumdu.edu.ua., phone 066-418-25-23.

Voronko Vitalii - Doctor of technical sciences, professor. Professor of the Department of Transport Systems and Logistics Kharkiv National University of Municipal Economy named after OM Beketova, Kharkiv, Ukraine, e-mail: Vitaliy.voronko@gmail.com, phone 050-578-97-33.

Gayda Pavlo - Candidate of Military Sciences, Senior Researcher. Associate Professor of Military Training, Sumy State University, Sumy, Ukraine, e-mail: info@kvp.sumdu.edu.ua., phone 066-397-50-11.

Pashchuk Alexander - Assistant of the Department of Structures and Design of Rocket and Space Technology of the National Aerospace University named after ME Zhukovsky "KHAl", Kharkiv, Ukraine, e-mail: paschuc1@gmail.com, phone 097382-61-45. 